\title{
Antibacterial Properties of Mentha pulegium
}

\author{
${ }^{*}$ Corresponding Author \\ Umar Yusuf \\ Article History \\ Received: 10.10 .2019 \\ Accepted: 18.10 .2019 \\ Published: 30.10 .2019
}

Umar Yusuf *, Musa Muhammad

Department of Pharmacology and Therapeutics, College of Health Sciences, Usmanu Danfodiyo University, Sokoto, Nigeria

\begin{abstract}
Most medicines used in the treatment of human diseases today are extracted from herbs that have been considered as an herbal medicine in traditional medicine. As the use of synthetic drugs and the emergence of pathogenic strains has increased, efforts to replace chemical drugs with cost-effective herbal remedies have increased. In this regard, every year many researchers from this huge plant source are sending a range of secondary compounds to the consumer market for the treatment of human diseases. Therefore, the identification of herbs with antimicrobial effects can help to produce new drugs with a broad spectrum of effects. This study, based on scientific references, describes information on the antimicrobial effects of Mentha pulegium.
\end{abstract}

Keywords: Medicinal Plants, antibacterial effects, Mentha pulegium.

\section{INTRODUCTION}

One of the major problems in antibiotic therapy today is the resistance and subsequent side effects of the drug. Accordingly, after researching the effects of plants, man has used them in various industries [1-2]. After the discovery of penicillin in the 40s, and its use in treatment, new antibiotics were introduced every day to treat infections [3-5]. The result was the expansion of the clinical use of natural and synthetic antibiotics in the treatment of clinical infections $[6,7]$. The overuse of these antimicrobial drugs has led to increased drug resistance against different antibiotics in most bacteria [8-10]. This has been one of the reasons for the growing use of herbs as low-risk, affordable, and inexpensive natural ingredients in the treatment of bacterial infections compared to synthetic antibiotics [11-13]. Also, these herbal remedies are more popular with people [14-16]. These reasons have been the reason for the increasing wave of new worldwide studies and the introduction of antibacterial effects of various plants in recent years [17]. It is estimated that at least one third of all products consumed are of plant origin. The use of herbal extracts for adjuvant treatment of microbial infections has attracted much attention today $[18,19]$.

\begin{abstract}
Mentha pulegium
Mentha pulegium is from the mint family and is one of the oldest medicinal plants with sedative, analgesic and antiseptic properties especially for the treatment of diabetes [20, 21]. Found in Europe, Australia, South Africa, the Mediterranean region, Turkey and eastern Iran [22]. Mentha pulegium treats sore throats, even microbial sore throats, and fights viruses and body infections [23]. The antioxidant in this plant strengthens the immune system and contains Rosmarinic acid and Thymol. Studies have shown that the compounds in Mentha pulegium fight cancer cells, as well as quercetin, which inhibit cancer cell growth and improves cell death [24]. Mentha pulegium leaves and flowers as well as its stems can be a good alternative to many antibiotics. Experiments have shown that Mentha pulegium extract is active against herpes virus, influenza virus, Newcastle disease and various other viruses. The nature of this plant is warm and dry [25]. In addition to its therapeutic effects, the plant is also used as a fragrance, spice and seasoning food the most effective combination of this plant is Pulegone and 1-8 cineol, which has antimicrobial properties [26, 27]. The leaves and branches of this plant are used as food and tea [28]. Although Mentha pulegium oil is highly toxic, consumption of fresh and dried herbs is common. It is used to treat colds, dizziness, headaches, gastrointestinal problems, mild fever, and sore throat and to improve abdominal flatulence, nausea, menstrual cramps and insomnia [29-30]. It grows well in mountainous areas, plains, and in humid places, and is widely used as a medicinal plant, especially for strengthening the immune system [31].
\end{abstract}

Copyright @ 2019: This is an open-access article distributed under the terms of the Creative Commons Attribution license which permits unrestricted use, distribution, and reproduction in any medium for non commercial use (NonCommercial, or CC-BY-NC) provided the original author and source are credited. 


\section{Antibacterial effects}

Antibacterial effects of Mentha pulegium on Gram-positive bacteria are more than Gram-negative bacteria, with the most reported effect on Staphylococcus aureus.

Table-1: The highest antibacterial effect of Mentha pulegium in studies

\begin{tabular}{|l|l|l|l|}
\hline \multirow{2}{*}{ Authors } & \multicolumn{2}{|l|}{ Most antibacterial effect } & \multirow{2}{*}{ References } \\
\cline { 2 - 3 } & Gram-positive bacteria: & Gram-negative bacteria: & \\
\hline Motamedi et al. & S. aureus & P. mirabilis & 32 \\
\hline Hajlaoui et al. & S. aureus & E. coli & 33 \\
\hline Mahmodi et al. & S. aureus & -- & 34 \\
\hline Basti et al. & S. aureus & Salmonella typhimurium & 35 \\
\hline Nozohor et al. & S. aureus & E. coli & 36 \\
\hline Gulluce et al. & S. aureus & E. coli & 37 \\
\hline Ceyhan-Güvensen et al. & S. aureus & Salmonella typhimurium & 38 \\
\hline Amalich et al. & S. aureus & E. coli & 39 \\
\hline Aycan et al. & S. epidermidis & E. coli & 40 \\
\hline Jazani et al. & -- & Klebsiella sp & 41 \\
\hline
\end{tabular}

\section{CONCLUSION}

Although many plants have been investigated to find antimicrobials so far, none of their antimicrobial compounds have been able to compete with common antibiotics, and the search for antimicrobial plant agents continues. Also, given the importance of medicinal plants and their derived metabolites in ensuring the health of human communities and the high economic potential of these plants, as a reliable source of income, a comprehensive and comprehensive plan should be developed in developing countries and devote part of agricultural biotechnology research to universities and research institutes on the identification, industrial production, and optimization of methods of extracting pharmaceutical metabolites from these plants.

\section{REFERENCES}

1. Jafari-Sales, A., Jafari, B., Sayyahi, J., \& Zohoori-Bonab, T. (2015). Evaluation of antibacterial activity of ethanolic extract of malva neglecta and althaea officinalis I. On antibiotic-resistant strains of staphylococcus aureus. J Biol Today World, 4(2), 58-62.

2. Gulluce, M., Sahin, F., Sokmen, M., Ozer, H., Daferera, D., Sokmen, A., ... \& Ozkan, H. (2007). Antimicrobial and antioxidant properties of the essential oils and methanol extract from Mentha longifolia L. ssp. longifolia. Food chemistry, 103(4), $1449-1456$.

3. Jafari-Sales, A., Shahniani, A., Fathi, R., Malekzadeh, P., Mobaiyen, H., \& Bonab, F. R. (2017). Evaluation of Antibacterial Activity of Essential Oil of Ziziphora clinopodioides and Achillea wilhelmsii on Antibiotic-resistant Strains of Staphylococcus aureus. Internal Medicine and Medical Investigation Journal, 2(2), 49-56.

4. Zainab, A., Bhat, R., Acharya, S., Yende, A., PS, P., \& Padyana, S. (2013). Studies on antioxidant and antimicrobial activities of Pajanelia longifolia (Willd.) Schumann. Obesity Research Journal. DOI, 10(2013.756484).

5. Sales, A. J., Shadbad, N. N., \& Kaleybar, V. P. (2015). The Investigation of the Antibacterial effects of Ethanol extract of Cichorium intybus L. on Antibiotic-resistant Staphylococcus aureus strains. Bull Env Pharmacol Life Sci, 4, 161-4.

6. Mobaiyen, H., Jafari Sales, A., \& Sayyahi, J. (2016). Evaluating antimicrobial effects of centaurea plant's essential oil on pathogenic bacteria: staphylococcus aureus, staphylococcus epidermidis, and escherichia coli isolated from clinical specimens. Journal of Fasa University of Medical Sciences, 5(4), 479-487.

7. Tunç, K., Hos, A., \& Gunes, B. (2013). Investigation of antibacterial properties of Cotinus coggygria from Turkey. Pol. J. Environ. Stud, 22(5), 1559-1561.

8. Jafari-Sales, A., \& Bolouri, P. (2018). Evaluation of the antimicrobial effects of Glycyrrhiza glabra I. on some gram positive and gram negative pathogenic bacteria in laboratory conditions.

9. Cowan, M. M. (1999). Plant products as antimicrobial agents. Clinical microbiology reviews, 12(4), 564-582.

10. Sales, A. J., Malekzadeh, P., Ebrahimzadeh, M., Kondlaji, K. B., Kaleybar, V. P., \& Dizaji, A. S. (2015). Journal of Science and Today's World. Journal home page: http://www. journalsci. com ISSN, 2322, 326X.

11. Sales, A. J., Bagherizadeh, Y., \& Malekzadeh, P. (2017). Evaluation of the Antimicrobial Effects of Essential Oil of Reseda Lutea L. on Pathogenic Bacteria: Staphylococcus aureus, Staphylococcus epidermidis, and Escherichia coli. Arch Clin Microbiol, 8(3), 1-5.

12. İşcan, G., Kïrìmer, N., Kürkcüoǧlu, M., Başer, H. C., \& DEMlrci, F. (2002). Antimicrobial screening of Mentha piperita essential oils. Journal of agricultural and food chemistry, 50(14), 3943-3946.

13. Jafari-Sales, A., \& Hossein-Nezhad, P. (2019). Antimicrobial effects of Rosmarinus officinalis methanolic extract on Staphylococcus aureus, Bacillus cereus, Escherichia coli and Pseudomonas aeruginosa in laboratory conditions. Journal of Medicinal and Chemical Sciences, 103-108.

14. Sales, A. J. (2014). Evaluation of antibacterial activity of ethanol extract of Lavandula Stoechas L. plant on antibiotic-resistant strains Of Staphylococcus Aureus. Journal of Current Research in Science, 2(6), 641. 
15. Mahboubi, M., \& Haghi, G. (2008). Antimicrobial activity and chemical composition of Mentha pulegium L. essential oil. Journal of ethnopharmacology, 119(2), 325-327.

16. Jafari-Sales, A., Rasi-Bonab, F., \& Sayyahi, J. (2019). The Survey on Antimicrobial Effects of Methanolic Extract of Carum Copticum L. on Staphylococcus Aureus, Bacillus Cereus, Escherichia Coli and Pseudomonas Aeruginosa in Laboratory Conditions. Paramedical Sciences and Military Health, 13(4), 19-25.

17. Sales, A. J., \& Shadi-Dizaji, A. (2019). Evaluation of Inhibitory Effect of Methanol Extract of Allium Sativum in vitro on Staphylococcus aureus and Escherichia coli.

18. Tajehmiri, A., Issapour, F., Moslem, M. N., Lakeh, M. T., \& Kolavani, M. H. (2014). In vitro antimicrobial activity of Artemisia annua leaf extracts against pathogenic bacteria. Advanced Studies in Biology, 6(3), 93-97.

19. Jafari-Sales, A., Hossein-Nezhad, P., \& Bolouri, P. (2019). Identification of chemical composition of essential oil and evaluation of antimicrobial effects of ethanolic extract of Mentha pulegium on Staphylococcus aureus and Escherichia coli.

20. Goodarzi, M., \& Nanekarani, S. (2014). Effects of feeding Mentha pulegium L. as an alternative to antibiotics on performance of broilers. APCBEE procedia, 8, 53-58.

21. Ait-Ouazzou, A., Lorán, S., Arakrak, A., Laglaoui, A., Rota, C., Herrera, A., ... \& Conchello, P. (2012). Evaluation of the chemical composition and antimicrobial activity of Mentha pulegium, Juniperus phoenicea, and Cyperus longus essential oils from Morocco. Food Research International, 45(1), 313-319.

22. Tassou, C. C., Drosinos, E. H., \& Nychas, G. J. E. (1995). Effects of essential oil from mint (Mentha piperita) on Salmonella enteritidis and Listeria monocytogenes in model food systems at 4 and $10 \mathrm{C}$. Journal of Applied Bacteriology, 78(6), 593-600.

23. Ehsani, A. L. I., \& Mahmoudi, R. (2013). Effects of Mentha longifolia L. essential oil and Lactobacillus casei on the organoleptic properties and on the growth of Staphylococcus aureus and Listeria monocytogenes during manufacturing, ripening and storage of Iranian white-brined cheese. International Journal of Dairy Technology, 66(1), 70-76.

24. Alpsoy, L., Şahin, H., \& Karaman, Ş. (2011). Anti-oxidative and anti-genotoxic effects of methanolic extract of Mentha pulegium on human lympocyte culture. Toxicology and industrial health, 27(7), 647-654.

25. Boukhebti, H., Chaker, A. N., Belhadj, H., Sahli, F., Ramdhani, M., Laouer, H., \& Harzallah, D. (2011). Chemical composition and antibacterial activity of Mentha pulegium L. and Mentha spicata L. essential oils. Der Pharmacia Lettre, 3(4), $267-275$.

26. Mahmodi, R., Tajik, H., Farshid, A. A., Ehsani, A., Zaree, P., \& Moradi, M. (2011). Phytochemical properties of Mentha longifolia L. essential oil and its antimicrobial effects on Staphylococcus Aureus. Armaghane danesh, 16(5), 400-412.

27. Brahmi, F., Abdenour, A., Bruno, M., Silvia, P., Alessandra, P., Danilo, F., ... \& Mohamed, C. (2016). Chemical composition and in vitro antimicrobial, insecticidal and antioxidant activities of the essential oils of Mentha pulegium $\mathrm{L}$. and Mentha rotundifolia (L.) Huds growing in Algeria. Industrial Crops and Products, 88, 96-105.

28. Tuzlacı, E. (2011). Türkiye'nin yabani besin bitkileri ve ot yemekleri. Alfa.

29. Ritchason, J. (1995). The Little Herb Encyclopedia: the handbook of nature's remedies for a healthier life. Houghton Mifflin Harcourt.

30. Kamkar, A., Javan, A. J., Asadi, F., \& Kamalinejad, M. (2010). The antioxidative effect of Iranian Mentha pulegium extracts and essential oil in sunflower oil. Food and Chemical Toxicology, 48(7), 1796-1800.

31. Marzouk, B., Fredj, M. B. H., Chraief, I., Mastouri, M., Boukef, K., \& Marzouk, Z. (2008). Chemical composition and antimicrobial activity of essential oils from Tunisian Mentha pulegium L. Journal of Food Agriculture and Environment, 6(1), 78.

32. Motamedi, H., Seyyednejad, M., Dehghani, F., \& Hasannejad, Z. (2014). Investigation of Antibacterial Activity of Ethanolic and Methanolic Extracts of Mentha pulegium L. Zahedan Journal of Research in Medical Sciences, 16(10), 55-59.

33. Hajlaoui, H., Trabelsi, N., Noumi, E., Snoussi, M., Fallah, H., Ksouri, R., \& Bakhrouf, A. (2009). Biological activities of the essential oils and methanol extract of tow cultivated mint species (Mentha longifolia and Mentha pulegium) used in the Tunisian folkloric medicine. World Journal of Microbiology and Biotechnology, 25(12), 2227-2238.

34. Mahmodi, R., Tajik, H., Farshid, A. A., Ehsani, A., Zaree, P., \& Moradi, M. (2011). Phytochemical properties of Mentha longifolia L. essential oil and its antimicrobial effects on Staphylococcus Aureus. Armaghane danesh, 16(5), 400-412.

35. Basti, A. A., Misaghi, A., \& Khaschabi, D. (2007). Growth response and modelling of the effects of Zataria multiflora Boiss. essential oil, $\mathrm{pH}$ and temperature on Salmonella typhimurium and Staphylococcus aureus. LWT-Food Science and Technology, 40(6), 973-981.

36. Nozohor, Y., Rasolifard, M. H., \& Ghahremanigermi, N. (2018). Evaluation of Antibacterial Properties of Oregano Essence on Pathogenic Bacteria Isolated from Hospital Infections. scientific journal of ilam university of medical sciences, 25(5), $154-160$.

37. Gulluce, M., Sahin, F., Sokmen, M., Ozer, H., Daferera, D., Sokmen, A., ... \& Ozkan, H. (2007). Antimicrobial and antioxidant properties of the essential oils and methanol extract from Mentha longifolia L. ssp. longifolia. Food chemistry, 103(4), $1449-1456$.

38. Ceyhan-Güvensen, N., \& Keskin, D. (2016). Chemical content and antimicrobial properties of three different extracts of Mentha pulegium leaves from Mugla Region, Turkey. Journal of environmental biology, 37(6), 1341-46.

39. Amalich, S., Zerkani, H., Cherrat, A., Dédianhoua, N., Soro, K., Bourakhouadar, M., ... \& Zair, T. (2016). Study on Mentha pulegium L. from M'rirt (Morocco): Antibacterial and antifungal activities of a pulegone-rich essential oil. J. Chem. Pharm. Res., 8(5), 363-370.

40. Aycan, M., Yildiz, M., Darcin, S., Tunc, K., Hos, A., \& Dundar, E. (2015). Antibacterial activity of Mentha pulegium L. from Turkey. American Journal of Life Sciences, 3(6), 383-386.

41. Jazani, N. H., Ghasemnejad Berenji, H., \& Sadegpoor, S. (2009). Antibacterial effects of Iranian Mentha pulegium essential oil on isolates of Klebsiella sp. Pakistan Journal of Biological Sciences, 12(2), 183-185. 